\title{
Synergistic Management: Harmonizing Management of Madrasah- Pesantren within One Framework as Integrated Educational Institution
}

\author{
Amin Maghfuri \\ UIN Sunan Kalijaga Yogyakarta \\ aminmaghfuri@yahoo.com \\ Sabarudin \\ UIN Sunan Kalijaga Yogyakarta \\ sabarudin@uin-suka.ac.id
}

\begin{abstract}
The existence of madrasas or schools based in pesantren portrays explicitly an integrated educational institution. Nevertheless, reality at the operational level does not fully indicate so. In fact madrasa and pesantren is managed partially rather than managed as an integrated education system. This article is intended to analyze the opportunities of synergizing the Islamic education system between pesantren and madrasas/schools gathered in one framework in order to become more effective islamic educational institutions. By using qualitative methode, the results of this study indicate that the opportunity to synergize pesantren and madrasas as alternative educational institutions is very wide open considering the education system that runs between the two is generally still separate. This step can be started by uniting management into an integral system, implementing an integrated and correlated curriculum and evaluating comprehensively. With the various excellences possessed by each pesantren and madrasa, synergizing these two institutions is the most effective way to realize a quality education output both in the field of religious knowledge and general knowledge.
\end{abstract}

Keywords: Islamic Education; Pesantren; Madrasab; Synergistic Management

Abstrak: Eksistensi Madrasah atau sekolah yang berbasis di pesantren secara eksplisit menunjukkan sebuah lembaga pendidikan integratif. Namun demikian, realita dalam tataran operasional kelembagaannya belum tentu menunjukean demikian. Dalam praktiknya banyak madrasah atau sekolah yang berbasis di pesantren tersebut secara kelembagaan dikelola secara terpisah tanpa ada keterkaitan antara keduanya. Artikel ini dimaksudkan untuk menganalisis kemungkinan mensinergikan pengelolaan lembaga pendidikan Islam antara pesantren dengan madrasah/sekolah dalam satu kerangka operasional dalam rangka menciptakan lembaga pendidikan yang efektif. Dengan menggunakan metode kualitatif, penelitian ini menunjukkan babwa peluang untuk mensinergikan pengelolaan pesantren dan madrasab/sekolah sangat terbuka lebar mengingat sistem pendidikan yang berjalan antara keduanya umumnya masib berjalan secara terpisah. Langkah ini dapay dimulai dengan menyatukan pengelolaan pengelolaan keduanya dalam satu kesatuan sistem yang integral, menerapkan kurikulum yang saling berkaitan dan terintegrasi serta menjalankan penilaian/evaluasi secara komprehensif. Dengan berbagai keunggulan yang dimiliki baik oleb pesantren maupun madrasah/sekolah, mensinergikan keduanya merupakan cara yang paling efektif untuk merealisasikan lulusan pendidikan Islam yang unggul baik, pengetahuan agama maupun pengetahuan umum.

Kata Kunci: Pendidikan Islam; Pesantren; Madrasab; Manajemen Sinergis 


\section{INTRODUCTION}

Pesantren is the most original and oldest Islamic education institution in Indonesia (Depag, 2003). Its existence takes part in coloring the history of education in Indonesia, especially Islamic education. Pesantren became an educational institution that existed before the independence of Indonesia was declared, and even it was believed to be the birthplace of the spirit for independence's struggle. After Indonesia'sindependence, pesantren still exists with various dynamics, and even pesantren can respondto negative assumptions about its resistance in dealing with the modern world by continuing to exist and continue to grow.

The survival of pesantrento this day is inseparable from its willingness and ability to adjust to the demands of the times, by modernizing almost all aspects inside. However, the dynamics that have occurred in pesantren so far still cannot be free from the slanted assumptions and pro and contras related to the pesantren's existence. Although most have begun to realize the role of pesantren-and madrassas as a result of pesantren modernization-in the context of educating the life of the nation, assumptions to be conservative or traditional are still always embedded in pesantren. Perhaps indeed pesantren and also the madrasas have not fully met the expectations of the community when juxtaposed with things that smell modern, although the process of modernization in pesantren, in particular, has been running a lot and is still ongoing.

One tangible form of the modernization process in the pesantren is the birth of madrassas within the pesantren environment which besides teaching religion, also accommodates the general sciences. Even though it takes quite a long time to reach an equivalent level of public schools that have been recognized by the government, the existence of this madrasa is still tangible evidence of a pesantren modernization process. Step by step and the dynamics that went through the pesantren until finally the government recognized it through a Joint Decree (SKB) Three Ministers illustrated how the process of modernizing the pesantren with the madrasa as an extension of his hand continued to run.

The pesantren modernization process which eventually gave birth to madrasas to meet the demands of the times is proof that pesantren are not antidevelopment institutions. The modernization, according to Maksum, was influenced by at least two things, namely as a result of the reforms that took place in the Islamic world and the response to the increasingly widespread public education made by the Dutch colonial (Maksum, 1999). The first factor indicates the awareness within the Muslim community itself-in this case, pesantren-of the need for innovations in Islamic education over the times. 
Whereas the second factor was an attempt by the pesantren to minimize the spread of secular education launched by the Dutch government.

Nevertheless, the development carried out by this pesantren basically begins with a deep dilemma(Mutohar \& Anam, 2013). Pesantren, which is actually an Islamic educational institution-in the narrow sense-that teaches only religious knowledge is required to include general knowledge that they even avoided. The dilemma that surrounds pesantren is between maintaining a historical identity as an institution for producing ulama and faqib (people who master an Islamic jurisprudence) or following the demands of modernization by including non-religious education to meet the requirementsof the workplace. Finally, gradually and continuously, pesantren accept the "pressure" of modernization by establishing madrassas representing pesantren institutions that also teach non-religious education. To this day, almost all traditional pesantren that were once considered anti-development institutions have had institutions that teach general education to meet the demands of the community in the form of madrasas, ranging from Madrasah Ibtidaiyah (MI), Madrasah Tsanawiyah (MTs), and Madrasah Aliyah (MA), and some have even established Higher Education.

\section{RESEARCH METHODS}

This study uses a qualitative method (Fathurrochman, 2019). The data's collection techniques carried out by literature review/literature study relating to the synergize the management of pesantren and madrasah/schools with qualitative research showing the results that this research provides an opportunity to synergize the management of pesantren and madrasah/schools is very wide open considering that the education system that runs between the two is generally still running separately (Fathurrochman, 2017).

\section{RESULT AND DISCUSSION}

The tendency to follow the real mainstream begun with the dilemma begins to show what was once feared. Massive changes made by pesantren also indirectly changed the orientation of the pesantren, as well as the community's view of the pesantren. The existence of Islamic educational institutions that also teach general knowledge-in this case, madrasa-on one hand, is able to cover the weaknesses of the pesantren and be able to meet the expectations of the public about graduates who are ready to work, even though the scale is still not optimal. But on the other hand, fears of Kyai (the leader of pesantren) that pesantren will be uprooted the historical roots of Islamic education began to show their indications. In addition, an in-depth study of Islamic-classical scientific treasures began to wane as the effect of refocusing education on the new subject. Though it was the most reliable methodon Islamic teaching in 
which thesanad can be justified to produce candidates of experts in these fields (Fathurrochman, 2019).

In addition to fears of uprooting the historical roots of Islamic intellectualism, the appearance of madrassas also had an impact onthe national education condition. Since its inception, the majority of madrassas were indeed used as a counterweight-not to say fight-against the educational policies applied by the colonial government. This fact raises a negative stigma for the world of education in Indonesia, which seems to expose both to a difference and conflict. The stigma seems to have become a dogma in people's lives since independence has not yet been achieved, even still carried over and rooted in people's perceptions untillndonesian independence in 1945 and until nowadays.

In the aftermath of Indonesia's independence, in the efforts of national development in which one of the focuses is on education, the government is faced with the reality of negative stigma in the Indonesian education world. The existence of two types of educational institutions that are considered by the public to be different and conflicting certainly has the potential to cause several problems. Although there are already public schools recognized by the government, it seems that putting aside madrassas is not an appropriate step considering that there is also quite a large amount of public interest in these institutions.

To reduce the dichotomic contention among the people, the government tried to overcome by issuing Presidential Decree No. 34 of 1972 concerning the unification of all educational institutions under the auspices of the Ministry of P\&K. The Presidential Decree was later strengthened by the issuance of Presidential Instruction No. 15/1974 so that Presidential Decree No. 34 of 1972 immediately realized(Maksum, 1999). From there, with various problems and dynamics, a three-ministerial decree was born on "Improving the Quality of Education in Madrasas" in 1975. The decree was a follow-up to Presidential Decree No. 34 of 1972 and Presidential Instruction No. 15 of 1974 in essence that madrasa is an educational institution under the responsibility of the Minister of Religion and its status is equivalent to public schools according to their level (Maksum, 1999).

However, this policy did not go as expected in the implementation. The dichotomic assumption remains and the "stepchild" of madrasa becomes a new reality on the ground. Madrasas on one hand are often regarded as second class schools with various shortcomings. On the other hand, madrasas are also starting to be considered less able to represent pesantren as successors and guardians of Islamic intellectualism and moral guardians of the nation's generation. As an extension and representation of pesantren, madrasas are not able to adequately describe the tradition of pesantren, especially after the Joint 
Ministerial Decree of three Ministers demanded a change in the orientation of the madrasa curriculum by decreasing religious content.

In the three ministerial joint decrees, the madrasa received the title as a public school characterized by "Islamic". Perhaps it was pinned because madrasa was nothing but an extension of the pesantren which was known as a place to acquire Islamic knowledge at that time. However, the embedding of the predicate is not necessarily followed by the quality of output from the madrasa. Graduates produced by madrasas tend not to be maximal and are considered to be very awkward. As a public school characterized with "Islamic", madrasas are not able to produce a graduate who has deep religious knowledge, and as a school that teaches a variety of general knowledge, madrasas are less able to produce generations of scientists who excel in the field of general knowledge, in this case, the knowledge taught is still quite low and inadequate (Raharjo, 2002).

This could be due to various reasons, starting from the professionalism of teachers, the completeness of learning facilities and infrastructure in madrasas, as well as other facilities that madrassas cannot fulfill. In addition to these reasons, time allocation of study in madrassas is certainly different from that in public schools due to the fact that there is more religious material in madrassas than in public schools.Though, in general, the allocated time for study between public schools and madrasas is almost the same. That may be more severe occur in madrassas within the scope of pesantren, in which religious learning is carried out on both (pesantren and madrasa), where religious material in madrasas is usually more basic or lighter than religious material in pesantren. This certainly makes the study time of students or santri less effective because there could be a repeat of the studying material, between the discussion of religious material in the pesantren and the madrasa.

\section{Pesantren and Its Dynamics}

In general, Pesantrenis known as an Islamic educational institution that specializes in providing education and teaching about Islamic religious knowledge. Pesantren which is the first Islamic educational institution in Indonesia come up along with the arrival of Islam in Indonesia. It is uncertain when the pesantren was first established and where the pesantren was first established. Quite a lot of opinions say when the pesantren began to be established with various arguments respectively. However, regardless of when pesantren was first established, this institution is recognized as an indigenous Islamic educational institution, the oldest and most original Islamic educational institution in Indonesia. Besides being identical with the meaning of Islambecause pesantren is an educational institution that specializes in teaching religious knowledge-the existence of pesantren is also identical to the meaning 
of authenticity in Indonesia (Madjid, 2010). Pesantren has a strategic role in the context of the spread of Islam at the beginning of the entry of Islam in Indonesia. The pesantren functions as a place to deepen religious knowledge as well as a place for cadres of ulemas or preachers to spread Islam in Indonesia.

Pondok Pesantren can be interpreted as religious institutions that provide education and teaching, develop, and spread Islamic religious knowledge. Pesantren is a system or institution of Islamic education in Indonesia that was born long before the existence of other education systems in Indonesia (Depag, 2003). The teaching method commonly used in the pesantren system issorogan or bandongan method. In addition, there are still methods in the form of discussions called deliberation classes (kelas musyawarah) which are usually only attended by senior students (Dhofier, 2011). In the deliberation class, it is discussed several aspects in a book (kitab kuning) that has been read by a teacher or kyai, including the grammar of language and content contained in the book (kitab kuning).

Pondok Pesantren as an educational institution has its own peculiarities when compared to other educational institutions such as schools. In pesantren, there are elements that will not be found in other schools or educational institutions. The existence of these elements is an important element in the running of the learning system in Islamic boarding schools. Generally, a pesantren must have these elements, but certainly between one pesantren with another has differences following the size of the pesantren. These elements include mosques, dormitories, recitation of classical Islamic books (kitab kuning), santri, and kyai (Dhofier, 2011).

As time goes by, based on the form and type of education, pesantren are generally known into two categories, namely pesantren salaf and pesantren khalaf. These two types of pesantren are now well-known and are often used as a comparison between the two. More specifically, Ridlwan Nashir classifies pesantren into five types, namely salaf/classical pesantren, semi-developing pesantren, developing pesantren, khalaf/modern pesantren (Erniati, 2017; Lukens-bull, 2010; Nashir, 2010).In addition, the classification of pesantren can also be seen from its contact with the school system. Based on the contiguity of the pesantren system with the school system, pesantren can be categorized into four types, namely 1) pesantren which are fully implemented traditionally; 2) Pesantren that conduct classical teaching; 3) Pesantren which are only boarding, while students study outside Pesantren; and 4) Pesantren that run the pesantren system as well as organizing a school or madrasa system (Arifin, 2012; Basyit, 2017). 


\section{Madrasa: History and Development}

In Islamic education discourse, the term madrasa is an important part that cannot be separated from the discussion. Its existence has taken root and has become a distinctive Islamic term that indicates an educational institution for a long time. The term was spread along with the widespread influence of Islam in parts of the world, including reaching Indonesia. As a Muslim-majority country, Indonesia is also not free from the use of the term madrasa to indicate an Islamic educational institution. However, there are several different meanings in mentioning the term madrasa in Indonesia when compared to mentioning the term elsewhere.

In the history of the world of Islamic education, the madrasa is a term to indicate an educational institution in general, in which there is a process of education and teaching that is quite extensive without any specialization. This is quite different from the history of Islamic education in Indonesia, where the madrasa was originally set up only as a place for religious education and teaching. In the madrasa at that time no knowledge was taught other than religious knowledge, even the madrasa was considered as an opponent or a form of rejection of general education. This is what distinguishes between madrassas in the world of Islamic education in general and madrassas in Indonesia. Madrasa in the Arab world is intended for all schools in general, whereas in Indonesia it is only intended for schools that teach religious knowledge, and in its development in schools where religious knowledge is the basis or its hallmark (Daulay, 2001).

The history of the birth and development of madrasas in Indonesia cannot be separated from pesantren. Madrasa is believed to be a continuation of the pesantren system which has been modified and developed based on the implementation of public schools using the classical system (Nashir, 2010). If this is not the case, it is the result of the interactions with the outside world and dissatisfaction with the teaching patterns that take place within the pesantren system. Efforts made by Indonesian Muslims who have gained experience outside Indonesia to reform Islamic education in Indonesia are manifested in the form of madrasa institutions. The spirit of this renewal is more or less caused by the renewal in the Islamic world in the middle east at that time. In addition, madrasas were generally born in response to the policies and education systems of the Dutch colonial government (Dawam \& Ta'arifin, 2005).

Initially in Indonesia, the term madrasa was identical to religious education without general education. But in its development, madrasas are flexible enough to incorporate general education into the madrasa system. It is rooted in the awareness of the importance of education to navigate life in the 
world, besides the importance of religious education for the appreciation of worship. Until now, in general, there are two types of madrasas in Indonesia, namely madrasas diniyah which only teach religious education and madrasa in the general sense which besides teaching religious knowledge also teaches general knowledge. After Indonesia's independence, this second type of madrasa received a lot of attention from the government, especially in the curriculum aspect. This is done primarily to provide recognition of equality in madrasas with public schools, so that madrasah graduates have the same rights as public school graduates.

The appearance of madrasas can not be separated from the various dynamics that occur in each of its time so that madrasas appear in diverse types such as public-managed madrassas, government-run madrassas or madrassas within the pesantren. Madrasas in this case always adjust or adapt to the needs and conditions of a particular time. Starting from the inclusion of little by little general knowledge in the madrasa, until the birth of the Joint Decree (SKB) of the Three Ministers about improving the quality of madrasas as a basis for equalizing madrassas with public schools. The many features of the madrasa require affirmation related to the type of madrasa discussed here so as not to confuse. The madrasas referred to in this discussion are madrasas based or integrated within the pesantren environment.

\section{Concept of Synergistic Managementbetween Pesantren and Madrasas}

The emergence of madrassas or schools in the pesantren education system was initially considered the most realistic solution for efforts to bring about changes in the framework of developing superior human resources not only in the field of religious knowledge but also excelling in the field of natural and skillful knowledge in the field of technology application (Lukens-bull, 2000; Rasyid, 2012). By combining prominent aspects of pesantren education institutions with school education institutions, it is assumed that this will be a way out for scientific dilemmas that are plaguing post-independence Indonesian society and especially considered unable to provide optimal support for the ongoing development process at the time. By combining the two excellences of the two educational institutions-Islamic boarding schools and schools/madrasait will automatically give birth to Indonesian human resource outputs that are ulama' yang ilmuan atau ilmuan yang ulama', to describe someone who masters religious scientific competencies and general scientific competencies at the same time (Lukens-Bull, 2005; Nurochim, 2016). Such an educational model is then described or represented by the birth of the madrasa in the pesantren education system.

The description of madrasa or school in such a way is indeed not a mistake. In the days when the madrasa was founded in the pesantren 
campaigned intensely, the purpose was indeed intended for the needs that were in line with the needs of the era at that time. With all the conditions that existed at that time, in which the existing educational institutions that were accessible to the wider community were the only pesantren, and because the educational model that runs within the pesantren system was deemed insufficient to meet the needs and demands that existed, the idea came out to establish or diversify the pesantren institution in the form of a school that still presents the values of the pesantren. Then the madrasa was born in the pesantren system and in its development, many were followed by other pesantren, apart from the encouragement of the government at that time.

But then, as time goes by and the dynamics that accompany each era, madrasa education or schools in the pesantren system are slowly 'separated' from the original system so that today it can be said that madrassas or schools within the pesantren environment generally 'separated' both institutionally and managementally with the pesantren. Pesantren and madrasa/school become their respective domains whose management is carried out by different actors. In this case, the modernization of pesantren which continues to take place quickly results in a side effect that is not disorienting the pesantren curriculum, between consistently holding traditions, creatively adopting change or a combination of both which in fact, does not reveal its success (Asmani, 2016).

This certainly makes the initial expectations of the establishment of madrasas in the pesantren system slowly began to fade. There is true that with the madrasa system, some aspects suchas the curriculum, the relevance of education and management of education are more structured and planned better than in the pesantren system. But perhaps there is something that has been overlooked or left behind from the educational transformation process, namely the substance or basic principles of pesantren to teach and train students or santri in mastering Islamic knowledge and values that are not accommodated properly or are not visible from modern institutions as a result of the renewal of pesantren. In other words, the madrasa has lost its orientation and historical roots, which this situation actually plays a role in the sharpening of the dualism of the meaning of education (Dawam \& Ta'arifin, 2005).

The dynamics of development that lead to the non-synergisticintegrative pattern between pesantren and madrasa occur in almost all places. Generally, these pesantren classify the education system they hold with an integrative or integrated label. However, "integrated" labeling is part of the "marketing product" to attract the interest of the wider community, even though the labeling is also not entirely wrong. At the very least, the integrative or integrated label is depicted from the implementation of formal education where students are at the same time required to stay overnight or live in a pesantren. With this pattern of education, the integrative or integrated label is 
considered to have been adequately represented even though it is in a very small scope.

In the author's view, the combined educational patterns between the pesantren system and the formal school system (school/madrasa) aforementioned do not fully describe an integrative or integrated, let alone synergistic. Although improvements are certainly also made, in general, there are patterns of relationships that require the pesantren system and the formal school system to not be integrated into one concept and a synergisticintegrative education system. In other words, although boththe pesantren system and the formal education system appear to be unified, substantially these two institutions have their own "soul" or "spirit". The pesantren education system stays with its "spirit" as a traditional institution and formal education system is consistent with its "spirit" to meet the demands of formality.

In fact, there have been many pesantren that hold integrated education patterns as the above conception. But it is no exaggeration to say in general that until now there has not been a pesantren with an integrated education pattern which is good in the field of general science education as well as good in the field of religious education. Some cases even show that the so-called pesantren with this conception is only a dormitory where students stay, or maybe even more boarding schools (sekolah berasrama) (Wahid, 2011).

The not-synergistic management of these two institutions (pesantren and madrasa) can be seen mainly from the application of the curriculum. Even though it is labeled with an integrated system, the application of the curriculum inside is carried out with a partial pattern, pesantren with its own curriculum and formal education with its own curriculum. In some places, managers even add curriculum content with religious subjects to the formal education system for certain reasons, even though madrasa education curriculum is generally already "overcapacity" compared to the public school curriculum with a greater number of religious subjects.

The existence of a greater number of religious subjects in the national curriculum should be followed by additional hours of study for madrasa students between 10-14 hours each week. So, even though the burden of subjects on madrasas is more, but with the availability of sufficient study time, the quality of madrasa graduates is predicted to be better in their religious fields and able to compete in the field of general science (Rosyada, 2017). But in reality, the number of study hours in madrassas is generally still the same, with a slight cut in the allocation of study hours for general knowledge material. Ironically, in some madrassas or schools based in pesantren, the allocation of learning time that is not in favor of these students must still be added to several types of subjects, such as kitab kuning and others. This, of course, will directly or 
indirectly affect the quality of learning in all subjects and especially in natural science materials.

Furthermore, as mentioned above, the management patterns of these two institutions generally still prioritize their "spirit" respectively. This can be seen from the compulsion of madrassas or schools (including those based in pesantren) to carry out education with a comprehensive national curriculum thoroughly. It means religious education in the national curriculum (which even in some places are still being added independently) must be applied absolutely because it is related to various aspects that describe formalism. Meanwhile, in the pesantren system, religious materials are also taught which are almost identical or even higher in the case of its content. This, according to the author, is a form of the overlapping curriculum in the conception of an integrated/integrative institution that wastes time. In my opinion, the overlapping of this time-wasting curriculum should be effective with a synergistic-integrative educational pattern between pesantren and madrasa/schools, so that mastery of religious knowledge and general knowledge can be maximized.

Madrasas or schools that are limited in terms of institutional integration with pesantren have the opportunity to synchronize their educational programs. With the pesantren, the opportunity for school or madrasa students to get deeper and broader religious studies is wide open, as is the opportunity to take seriously the natural knowledge in schools(Nurochim, 2016). With the existing religious learning system in pesantren, there is really no need for religious learning in schools, of course, if the concept of integrative-synergistic education has been realized. Do not let the existence of pesantren be considered only as an aspect or supporting component for the implementation of formal school education, whether madrasas or public schools within the pesantren environment.

Opportunities to create non-dichotomic education - in the sense that there is an equal emphasis between general science and religious science - are very wide open in the integration of school/madrasah and pesantren institutions. Through these integration institutions, students will get equally good learning between general science and religious knowledge, so that it will affect the quality of their lives in the future. The pesantren has a superior system in matters of religious education that are not owned by schools or madrassas. Whereas schools or madrasas usually tend to pursue mastery of their natural sciences, although sometimes madrasas are quite far behind. By utilizing the advantages of both through building a synergistic-integrative system, it is expected that the quality of the output of graduates will truly be insan kamil, a Muslim and our servant and a qualified Caliph of Allah. 
The synergistic-integrative system conceptualization between pesantren and madrasa/school demands a comprehensive reconstruction of the education system. The reconstruction must be carried out within the framework of effective education management, starting from the management pattern, curriculum, facilities, and infrastructure as well as assessment. These all must be done within an integrated management framework, united with a universal and same spirit. This must be done because so far what makes these two educational institutions (madrassas/school and pesantren) not synergistic is a separate, partial and operational pattern that runs with their own "spirit".

In more detail at the conceptual level, the synergistic-integrative reconstruction of the education system can be seen in the following explanation:

\section{Management of Institutions}

First of all that deserves attention is the management system. All this time, the management of these two institutions tends to be separate and individual. As mentioned earlier, each institution has its own "spirit" and has its own direction of the struggle. Although there are aspects that intersect, the management tends to differ in spirit and procedure. This can not be denied as a consequence of the management pattern of education in Indonesia that is not integrated. At the ministry level, for example, education is under the auspices of two ministries, the ministry of education and culture (Kemdikbud) and the ministry of religion (Kemenag). The existence of two parties responsible for education indirectly actually reinforces the line of educational differences on a general basis and a religious basis. Even if it is said that pesantren and madrasa are both under the auspices of the ministry of religion, the unified management pattern can still be seen from the existence of directorate in each of the two institutions. However, what really matters in the discussion here is the pattern of management that is not integrated between madrassas and pesantren at the operational-technical level.

In almost every pesantren that includes formal institutions inside, the management of education between the two is done separately or at least shows something that is out of sync. This is influenced by the spirit that gives rise to different opinions related to the goals of these two institutions. Professional management is generally only applied to formal institutions, while pesantren are managed modestly. In many places, formal education institutions receive higher priority, while pesantren are sometimes only seen as complementary without any connection to the education system at formal institutions.

This kind of management model needs to be improved and developed in a better direction. Moreover, when viewed from a historical perspective, basically pesantren and madrasa have close links and have the same goals. Integrated management that reflects the synergistic-integrative spirit between 
the two is needed to create an effective and balanced education system. This can be achieved if the management of these two institutions is in an integral concept, there is no distinction between pesantren and madrasa in terms of priorities, goals and the spirit of its management. In other words, the management of pesantren and madrasa must be in one framework, seen as an integral combination of institutions and having the same goal.

At the operational level, this integral institution can be led by one or more leaders or one leader with managers in each institution. But what needs to be stressed is, both must go together, with the same spirit and the same goal. By doing so, the realized education system is balanced and complement each other. Education with the running school system and with the pesantren or madin system also runs within a complete conceptual framework. There is no more jealousy because one is a priority and the other is ignored. There is no longer anyone that must follow the rhythm of one of the other, both run with the same rhythm and are synergistic.

\section{Curriculum}

Another matter that needs attention is the curriculum of this integrated institution. To realize a synergistic-integrative system, the applied curriculum must also be a unity that is run based on integral and same purpose. What has happened so far is that formal schools run with their own curriculum (national curriculum) and education in pesantren run with their own curriculum. There is often a "coercion" of the pesantren curriculum in the formal school curriculum only to get the attention and enthusiasm of students because it is also an aspect in which will be assessed to determine the final results. Besides, in terms of content as explained previously, especially in terms of religious material, there is an overlap between the curriculum in pesantren and the curriculum in formal schools.

Integrative and mutualist curriculum planning between pesantren institutions and madrassas should be directed to reduce or even eliminate the overlapping learning materials that exist in the education system. As an integral education system, overlapping curricula - especially the religious curriculum between pesantren and madrasa should be minimized and then effective so that there is no waste of time. The effectiveness of the religious curriculum can be utilized by educational institutions to optimize student mastery of the curriculum or other material, especially on natural knowledge and technology. By doing so, students or santri can learn with a maximum of existing learning materials, both in general knowledge and religious knowledge.

The curriculum planning indirectly requires a "separation" of the teaching domain in pesantren or madrasa. The word separation is used only as an explanation of what must be included in the madrasa domain and what should be included in the pesantren domain as an integral institution. Pesantren 
as an institution that has been proven in a real and convincing way of giving birth to qualified generations in religious affairs should be given the responsibility to manage the religious domain in the integral curriculum. Whereas madrasa, as an institution that was originally designed to provide general knowledge, is mandated to manage the domain of general knowledge without having to bother themselves and spend time managing the religious domain that has been held by the pesantren. By doing so, synergistic and integrative learning processes between pesantren and madrasa will be created harmoniously.

So far, in many madrasas based on pesantren, the management of religious education tends to overlap, where religious learning which is clearly the domain of pesantren, is also taught in madrassas. This is certainly a waste of time because, besides there is a repetition, religious material between the two institutions generally has different levels. And unfortunately, generally religious learning conducted in madrasas only repeats what has been taught in pesantren. Even what is taught in Islamic boarding schools has been far higher in level than that taught in madrassas. This is an opportunity for the effectiveness and optimization of religious learning.

With the implementation of a synergistic integral curriculum, the overlap as happened so far will be eliminated. However, this curriculum planning must truly reflect a unified and balanced emphasis. The curriculum must run together, the general material learning curriculum cannot be applied if the religious material learning curriculum is not implemented, and vice versa. With the separation of domains as explained earlier, the implementation of this integral curriculum should not be impossible to run. What needs attention is on pesantren learning which must be further improved both through upgrading teaching methods, class stratification, and materials and assessment as an inseparable part of assessments in formal schools. If deemed necessary, religious materials taught in pesantren can also be adjusted to the themes that are considered necessary and more useful.

\section{Assessment and Evaluation}

Among the aspects that determine the synergy-integrative conception of education in the combination of pesantren and madrasa institutions as an integral institution is the evaluation and assessment system. As it is known that so far the evaluation and assessment of the two institutions which are running partially and separately have different implications. Madrasas as formal institutions implement rigorous evaluation and assessment because they have the power to press on the usefulness of the results of the assessment in the future. Whereas pesantren, which are non-formal institutions, generally adopt a more lenient evaluation system and even without evaluation and assessment because it has no influence or sometimes seen as not very useful. Even 
pesantren that apply rigorous evaluations and assessments, the results are formally not recognized. Finally, the results of the evaluation and assessment are only in the form of a piece of paper that is not very useful for the life of the owner.

It indirectly impacts on students' enthusiasm for learning to pursue qualification or certificate formalities and a little ignores those that have no formal value. In the case of madrassas or schools, students and teachers give high priority to subjects that are subject to national examinations and ignore material that is not nationally tested, including religious subjects. Such formalisms, unfortunately, have infected life in general and can hardly be dammed. However, although all this time the determination of graduation is based on the test scores of the subjects being tested, in the view of the researchers, the educational institution can certainly determine or improvise on the graduation requirements of a student. This is where the opportunity for integral institutions, in the conception of researchers, to evaluate and assess learning.

If blocking the flow of formalism is almost impossible to do, then it is not a mistake if an educational institution creates conceptions to offset the formalism. The concept is intended to make policies at the institution level related to graduation requirements that must be met by a student, besides the results of the national exam scores. Thus, the implementation and emphasis on the application of the curriculum can be carried out in a balanced manner at these integral institutions.

Evaluations and assessments on these integral institutions can take various forms, especially related to religious materials. Evaluations and assessments which so far have generally only been able to accommodate cognitive aspects can be developed to be able to accommodate aspects of affection and psychomotor. In integral institutions, this is certainly very possible because so far the concept has been running. Even if improvements are needed, improvements can be made to the programmed and organized aspects of planning and implementation.

The conception of evaluation and assessment carried out thoroughly and proportionally at the same time also illustrates the complementary relationship between the madrasa system and the pesantren system. The percentage of assessment given must be the same so that both have the same effect on graduation and have the same pressure. If this is the case, there are no more students or teachers who ignore or underestimate certain subjects. The last expected outcome is the creation of a balanced educational output in the mastery of science between religious knowledge and general knowledge so that the dream of having an ulama yang ilmuan and ilmuan yang ulama in large numbers 
can actually be realized.(Rouf, 2016)(Zainiyati, 2015)(Azra, 2015; Maksudin, 2018)(Yunus, 1995; Zayadi, 2005)(Steenbrink, 1994; Yasmadi, 2002)

\section{CONCLUSION}

The conceptualization of an integrated and synergic Islamic educational institution between pesantren and madrasa suggests the need for evaluation and reconstruction of the existing system. With the various excellences possessed by each pesantren and madrasa, synergizing these two institutions is the most effective way to realize a quality education output both in the field of religious knowledge and general knowledge. This process is also able to show that both religious education and general education can be carried out together in a synergistic frame. Thus, the assumption of the dichotomy of science that has long been rooted will be eliminated.

\section{REFERENCES}

Arifin, Z. (2012). Perkembangan Pesantren di Indonesia. Pendidikan Agama Islam, IX(1).

Asmani, J. M. (2016). Peran Pesantren Dalam Kemerdekaan dan Menjaga NKRI (A. Pressindo, ed.). Yogyakarta.

Azra, A. (2015). Genealogy of Indonesian Islamic Education: Roles in The Modernization of Muslim Society. Heritage of Nusantara; International Journal of Religious Literature and Heritage, 4(1).

Basyit, A. (2017). Pembaharuan model pesantren : respon terhadap modernitas. Kordinat, XVT(2), 293-324.

Daulay, H. P. (2001). Historisitas dan Eksistensi Pesantren, Sekolah, dan Madrasah. Yogyakarta: Tiara Wacana.

Dawam, A., \& Ta'arifin, A. (2005). Manajemen Madrasah Berbasis Pesantren (L. F. Putra, ed.). Jakarta.

Departemen Agama Republik Indonesia. (2003). Pondok Pesantren dan Madrasah Diniyah: Pertumbuban dan Perkembangannya. Jakarta: Direktorat Jenderal Kelembagaan Agama Islam.

Dhofier, Z. (2011). Tradisi Pesantren: Studi Pandangan Hidup Kyai dan Visinya Mengenai Masa Depan Indonesia (Revisi). Jakarta: LP3ES.

Erniati. (2017). Reform of The System of Education In Pesantren. Hunafa: Jurnal Studia Islamika, 14(1), 37-58.

Fathurrochman, I. (2017). Implementasi Manajemen Kurikulum Dalam Upaya Meningkatkan Mutu Santri Pondok Pesantren Hidayatullah/Panti Asuhan Anak Soleh Curup. Tadbir: Jurnal Studi Manajemen Pendidikan. https://doi.org/10.29240/jsmp.v1i1.216

Fathurrochman, I., Budiman, D. A., Alamsyahril, \& Kristiawan, M. (2019). Revitalization Management Of Islamic Boarding School Preventing The 
Radicalism. Restaurant Business, (10), 495-505. Retrieved from https://journals.eduindex.org/index.php/rb/article/view/9462

Fathurrochman, I., Ristianti, D. H., \& Arif, M. A. S. bin M. (2019). Revitalization of Islamic Boarding School Management to Foster the Spirit of Islamic Moderation in Indonesia. Jurnal Pendidikan Islam, 8(2), 239-258. https://doi.org/10.14421/jpi.2019.82.

Lukens-bull, R. (2000). Teaching Morality: Javanese Islamic Education In A Globalizing Era. Journal of Arabic and Islamic Ctudies 3, (March).

Lukens-bull, R. (2010). Madrasa By Any Other Name Pondok, Pesantren, and Islamic Schools in Indonesia and Larger Southeast Asian Region. Journal of Indonesian Islam, 04(01).

Lukens-Bull, R. (2005). A Peaceful Jihad; Negotiating Identity and Modernity in Muslim Java. England: Palgrave Macmillan.

Madjid, N. (2010). Bilik-Bilik Pesantren: Sebuah Potret Perjalanan. Jakarta: PT Dian Rakyat.

Maksudin. (2018). Integration of school and pesantren educational system as a model of character education: perspective of educational transformation. International Journal on Islamic Educational, 2(1), 32-59.

Maksum. (1999). Madrasah: Sejarah dan Perkembangannya. Jakarta: Logos Wacana Ilmu.

Mutohar, A., \& Anam, N. (2013). Manifesto Modernisasi Pendidikan Islam dan Pesantren. Yogyakarta: Pustaka Pelajar.

Nashir, M. R. (2010). Mencari Tipologi Format Pendidikan Ideal: Pondok Pesantren di Tengah Arus Perubahan. Yogyakarta: Pustaka Pelajar.

Nurochim. (2016). Sekolah Berbasis Pesantren Sebagai Salah Satu Model Pendidikan Islam Dalam Konsepsi Perubahan Sosial. Al-Tahrir, 16(1).

Raharjo. (2002). Madrasah Sebagai The Centre of Excellence. In Ismail (Ed.), Dinamika Pesantren dan Madrasah. Yogyakarta: Pustaka Pelajar.

Rasyid, R. (2012). The Integration of The National Curriculum Into Pesantren Education System. JICS A, 01(02).

Rosyada, D. (2017). Madrasab dan Profesionalisme Guru dalam Arus Dinamika Pendidikan di Era Otonomi Daerah. Depok: Kencana.

Rouf, M. (2016). Manajemen Kurikulum Integratif Madrasah - Pesantren. AlHikmah; Jurnal Studi Keislaman, 6(September), 1-21.

Steenbrink, K. A. (1994). Pesantren Madrasah Sekolab: Pendidikan Islam dalam Kurun Modern. Jakarta: LP3ES.

Wahid, S. (2011). Transformasi Pesantren Tebuireng: Menjaga Tradisi di Tengah Tantangan. Malang: UIN Malang Press.

Yasmadi. (2002). Modernisasi Pesantren: Kritik Nurcholish Madjid Terhadap Pendidikan Islam Tradisional. Jakarta: Ciputat Press.

Yunus, M. (1995). Sejarah Pendidikan Islam di Indonesia (IV). Mutiara Sumber 
202 |Tadbir : Jurnal Studi Manajemen Pendidikan, Vol. 5, No. 2, 2021

Widya.

Zainiyati, H. S. (2015). Integrasi pesantren dalam sistem pendidikan tinggi islam : Studi di UIN Malik. Journal Education, 7(2).

Zayadi, A. (2005). Desain Pengembangan Madrasah. Jakarta: Dirjen Kelembagaan Agama Islam. 